\title{
Inventing a Fishbowl: White Supremacy and the Critical Reception of Lorraine Hansberry's A Raisin in the Sun.
}

\section{Citation}

Bernstein, Robin. 1999. Inventing a fishbowl: White supremacy and the critical reception of Lorraine Hansberry's A raisin in the sun. Modern Drama 42(1): 16-27.

\section{Published Version}

http://muse.jhu.edu/journals/modern_drama/

\section{Permanent link}

http://nrs.harvard.edu/urn-3:HUL.InstRepos:3659695

\section{Terms of Use}

This article was downloaded from Harvard University's DASH repository, and is made available under the terms and conditions applicable to Other Posted Material, as set forth at http:// nrs.harvard.edu/urn-3:HUL.InstRepos:dash.current.terms-of-use\#LAA

\section{Share Your Story}

The Harvard community has made this article openly available. Please share how this access benefits you. Submit a story.

Accessibility 


\title{
Inventing a Fishbowl: White Supremacy and the Critical Reception of Lorraine Hansberry's A Raisin in the Sun
}

\author{
ROBIN BERNSTEIN
}

When Lorraine Hansberry's A Raisin in the Sun opened on Broadway in 1959. the vast majority of white critics praised the play's "universality." One reviewer wrote, "A Negro wrote this show. It is played, with one exception, by Negroes. Half the audiences here are Negroes. Even so, it isn't written for Negroes .... It's a show about people, white or colored .... I see 'A Raisin in the Sun' as part of the general culture of the U.S."' The phrase "happens to be" appeared with remarkable frequency among reviews: the play was "about human beings, who happen to be Negroes"2 (or "a family that happens to be colored"3); Sidney Poitier played "the angry young man who happens to be a Negro."4

Other white reviewers, however, praised the play not for its universality, but for its particularity. "The play is honest," wrote Brooks Atkinson, critic for the New York Times. "[Hansberry] has told the inner as well as the outer truth about a Negro family in the southside of Chicago at the present time."5 "This Negro play," wrote another reviewer, "celebrates with slow impressiveness a triumph of racial pride." 6

How can a play be simultaneously specific and universal? This apparent paradox is easily resolved with the assertion that African-Americans are precisely as human - and African-American cultures just as universal or particular - as members of any other group. Hansberry herself pointed out the nonexistence of the paradox:

Interviewer: The question, I'm sure, is asked you many times - you must be tired of it - someone comes up to you and says: "This is not really a Negro play; why, this could be about anybody! It's a play about people!" What is your reaction? What do you say?

Hansberry: Well[,] I hadn't noticed the contradiction because I'd al ways been under the impression that Negroes are people .... One of the most sound ideas in dramatic 
writing is that in order to create the universal, you must pay very great attention to the specific. ${ }^{7}$

Hansberry's solution to the apparent paradox did not go unnoticed or unremarked. Novelist John Oliver Killens and historian and editor Lerone Bennett, Jr., for example, both noted Hansberry's ability to be "universal in her particularity."

The paradox, then, is that a paradox was perceived at all, or that it continued to be perceived after Hansberry (and, later, Killens, Bennett, and others') had publicly resolved it. Why did critics persistently categorize Raisin as either universal or specifically black? Why, when critics noted the fact that the play successfully communicated both universal and particular concerns, did they remark on this fact as a paradox or contradiction? In other words, why was the appearance of a paradox created and maintained?

This essay attempts to tease out some of the meanings fueling and produced by the creation and maintenance of the apparent contradiction between universality and particularity. Although the focus, obviously, is on A Raisin in the Sun, the same apparent paradox is constructed for many other artistic works from the past and present. This essay, then, (a) lays groundwork to analyze the apparently contradictory claims that a piece (any piece) is both "universal" and "specific" to a minority experience and (b) helps illuminate the reasons for a cultural need for the appearance of the paradox.

The claim that the play's characters are universal "people" without specific ties to African-American culture appears simply racist ("This is a well-written play; white people can relate to it; therefore it cannot be a black play"). Conversely, the assertion that the play is not universal but exclusively specific to African-Americans - that is, that the characters exist outside the category of "human" - seems equally racist. Upon closer examination, however, it is possible to discem both racist and anti-racist impulses in each claim.

The "particularizing" assertion can be separated into several different strands. In the most racist form, critics in this mode refused to acknowledge any difference between Hansberry's characters and stereotyped images of blacks. A few months after the play opened, Hansberry noted "some of the prior attitudes which were brought into the theatre from the world outside. For in the minds of many. [the character of] Walter remains, despite the play, despite performance, what American racial traditions wish him to be: an exotic."10 If audiences went to the theatre to see "the simple, lovable, and glandular 'Negro,"'ll they would find him, regardless of what actually occurred on stage. Hansberry wrote,

My colleagues and I were reduced to mirth and tears by that gentleman writing his review of our play in a Connecticut paper who remarked of his pleasure at seeing how "our dusky brethren" could "come up with a song and hum their troubles away." It did 
not disturb the writer in the least that there is no such implication in the entire three ucts. He did not need it in the play: he had it in his head. '

Similarly, Elliot Norton wrote for the Boston Record that Hansberry's characters "have been endowed with the light-hearted humor which seems to be inherent to their race." 13

Such blatant racism is related to the more subtle "people's culture" approach Eric Lott attacked in Love and Theft: Blackface Minstrelsy and the American Working Class. Lott defined the "people's culture" position as one that views minstreisy as a more-or-less accurate reflection or aspect of "authentic" Negro culture. Lott's attack on this approach's ahistoricity and inaccuracy might seem inapplicable to Raisin, which was obviously and deliberately locatable in black culture. However, the "people's culture" stance resembled that of some of the reviewers in that both approaches sought - or demanded - access to "authentic" black culture, as evidenced in critics" repeated praising of Raisin as "honest drama" with "vigor as well as veracity."' In other words, the "people's culture" approach and that of some of Raisin's critics shared a common impulse to access perceived authentic black culture. And in doing so. of course, these approaches re-asserted whiteness as the norm.

The play's ability to appear to encapsulate "Negro experience" in the readily knowable, digestible, and non-threatening form of theatrical realism arguably satisfied this impulse and thus constituted the primary reason for the play's success among white audiences. In other words, the play's realism satisfied its white viewers in much the same way that minstrelsy satisfied its viewers by providing them with easy access to consumable, perceived "Negro culture." $A$ Raisin in the Sun. then, by making black experiences appear understandable to and consumable by white audiences, simultaneously made those experiences collectable. The bourgeois white viewer could display his or her new-found knowledge much as one might display a collection of "primitive" art; as James Clifford argues, "cultural description [can be] presented as a form of collecting." 15

Collecting is a performance of power. To collect is to construct, limit, contain, display, and define. As Clifford observed, collections (even nonmaterial ones such as collected experiences of theatregoing) are necessarily organized taxonomically and hierarchically; thus collectors assent power over their possessions (which serve as metonyms for cultures). ${ }^{16}$ The impulse for the white theatregoer to collect knowledge of "authentic" black experiences - through minstrelsy or through Raisin's realism - is therefore an impulse to perform (and thus actualize) white power.

Collecting is closely related to conservation, another performance of power to which Clifford devoted some attention: "Collecting - at least in the West. where time is generally thought to be linear and irreversible - implies a rescue 
of phenomena from inevitable historical decay or loss."17 Clifford described the collecting of "primitive" visual art and the anthropological collecting of nonmaterial knowledge as similarly conservative projects: "Both discourses assume a primitive world in need of preservation, redemption, and representation."18 White audiences' nonmaterial collecting of minority experiences through theatre attendance, then, could involve a similar conservative impulse. And, as Clifford's colleague Donna Haraway noted, conservation is always intertwined with subjugation: "Once domination is complete, conservation is urgent."'19

Finally, the assertion that $A$ Raisin in the Sun was specifically and exclusively black effectively erased from the play Hansberry's class analysis. Many African-American critics and scholars have noticed and commented on this aspect of the play, but almost no white commentators have. Hansberry complained,

Some writers have been astonishingly incapable of discussing [the character of Walter's] purely class aspirations and have persistently confounded them with what they consider to be an exotic being's longing to "wheel and deal" in what they consider to be (and what Walter never can) "the white man's word."20

The erasure of Hansberry's class analysis suggests white critics' unwillingness to engage with a black writer's intellect. In other words, white audiences who came to the theatre to see (and collect the experiences of ) the "simple, lovable, and glandular 'Negro"'21 (and who encountered, to their disappointment, non-stereotyped characters ${ }^{22}$ ) could have preserved their mission by willfully ignoring anything that did not contribute to that project. Even the FBI, which investigated Lorraine Hansberry as a possible "danger to the Republic," labeled the play "not propagandistic."23 This description, regarded as flattering by the FBI, revealed an unwillingness to engage with - or even recognize - the politics of the play.

By ignoring Hansberry's politics and recognizing only the play's specificity to black culture, white critics erased Hansberry's authority to speak about anything but herself. This action positioned blacks as if in a fishbowl: they could look at each other, but not at anything beyond their immediate context. This fishbowl could sit comfortably, decoratively, on a shelf in a white household; white people could peer through the glass (which contained and controlled the exotics and simultaneously kept the white spectator safely separated from the creatures) and enjoy their collection. In other words, erasing Hansberry's authority to speak about anything but her (white-defined) culture created a "glass" barrier that separated white audiences from the play's black creators and characters and rendered the subaltern collectable - and thus produced white power.

Furthermore, this "fishbowl" dynamic created a unidirectional gaze; that is 
to say, it positioned blacks as the object of both blacks' and whites' gazes, and simultaneously positioned whites as the empowered, invisible inspector. This action reified blacks' lives and experiences as collectable and simultaneously precluded the possibility of blacks inverting the dynamic and collecting (and thus disempowering) whites and their experiences. The fish cannot collect the humans outside the bowl.

The interpretation of Raisin as specifically black (and distinctly not universal), however, also had non-racist, or even anti-racist. aspects, most of which originated from African-American writers.

Hansberry wrote the play in response to a racist performance:

One night, after seeing a play I won't mention, I suddenly became disgusted with a whole body of material about Negroes. Cardboard characters. Cute dialect bits. Or hipswinging musicals from exotic sources. ${ }^{24}$

The critic from Connecticut, then, was not entirely wrong when he read racist stereotypes into Hansberry's play: these stereotypes were diegetically present.

Black audiences apparently also read the play in the context of racist stereotypes. According to James Baldwin, the play drew unprecedented numbers of African-Americans to the theatre because "never before in American theater history had so much of the truth of black people's lives been seen on stage."25. Overiap occurred, then, between the racist impulse to collect black experiences and the anti-racist impulse to see one's own experience reflected on stage (and to see stereotypes extirpated): both impulses hinged on the highly suspect notion of authenticity. The fact that two opposing impulses could exist in the same space contributed to the appearance of a paradox.

The play itself emphasized particularity within particularity through the character of Joseph Asagai, a Nigerian. According to Alex Haley, Hansberry achieved two goals through the character of Asagai. First, she

helped to dispel the myth of the 'cannibal' with a bone in his hair. Her educated African character ... was certainly the first time a large audience had seen and heard an African portrayed as carrying himself with dignity and being, moreover, a primary spokesman for sanity and progress. It must also have been the first time a mass audience had ever seen a black woman gracefully don African robes or wear an "afro" hairstyle. ${ }^{26}$

Asagai, then, continued Hansberry's project of creating individual, specifically black characters who testified against stereotypes. Second, as Haley noted, $A$ Raisin in the Sun was the first artistic work to popularize (on a large scale) the concept of a relationship between African-Americans and Africans. ${ }^{27}$ By teasing out this relationship that specifically separated AfricanAmericans from all other Americans, Hansberry again employed the particularizing approach - but to anti-racist ends. 
As several critics - and Hansberry herself - have noted, however, Hansberry's particularism funneled into her universalism. Margaret B. Wilkerson posited that Hansberry's simultaneous particularism and universalism enabled Raisin to function as a bridge:

Hansberry ... [insists] upon a thorough probing of the individual within the specifics of culture, ethnicity and gender. In the midst of her expansiveness, she refuses to diminish the pain, suffering or truths of any one group in order to benefit another, a factor which makes her plays particularly rich and her characters thoroughly complex. Hence, she can write authentically about a black family in A Raisin in the Sun and yet produce, in the same instance, a play which appeals to both Blacks and whites, bridging for a moment the historical and cultural gaps between them.

Her universalism, which redefines that much abused term, grows out of a deep, complex encounter with the specific terms of human experience as it occurs for Blacks, women, whites and many other groups of people. Her universalism is not facile, nor does it gloss over the things that divide people. She engages those issues, works through them, to find whatever may be, a priori, the human commonality that lies beneath. ${ }^{28}$

Obviously, there was an anti-racist project inherent to the demand that white audiences see themselves (i.e., the "universal") in black characters. And audiences responded to this demand: scholars such as Lerone Bennett, Jr., commented on the "curious identification some elements of the non-black community felt toward the play." 29 However, within this dynamic - which Hansberry deliberately created from an anti-racist politic - racist interpretations abounded.

The universalist interpretation of the play was used to deny and erase the particularity on which Hansberry insisted. In this way, universalism functioned much like the collecting instinct of the "people's culture" approach: the latter sought black culture in order to acquire and preserve it - and thus assert power over it; the former denied and erased black culture in onder to control and assert power over it. Once again, opposing projects overlapped and contributed to the appearance of a paradox.

Furthermore, critics' lauding of Raisin for its "universal" appeal must be read in the context of the critics' more typical dismissal of black theatre "as social rather than artistic, as parochial rather than universal." 30 The interpretation of Raisin as artistic (i.e., apolitical) and universal, then, in addition to erasing crucial components of the play, denigrated all other black theatre. The elevation of Raisin to the status of universal made the play a token.

More subtly, the universalist impulse among white critics functioned to absorb the particular into the white/universal or to reduce the particular other to a reflection of the white self - both of which had the effect of inflating the white/universal. ${ }^{31}$ In an essay on an exhibit of "primitive" art at the Museum 
of Modem Art, Clifford described a "disquieting quality of modemısm: its taste for appropriating or redeeming othemess, for constructing non-Westem arts in its own image, for discovering universal, ahistorical 'human' capabilities. "32 The point is not that Hansberry's work was modemist or non-Westem, but rather that white critics, thinking in the modemist mode, treated Raisin as an exotic "other" and therefore sought "universal" qualities within it. Again, nuances of the apparent paradox are revealed: universalism flows into particularism, which in tum flows back into universalism.

What should be clear from this discussion is the fluidity, overlap, and mutual permeability of the categories of "universal" and "particular." Fluidity, overlap, and mutual permeability do not, however, constitute a paradox (which would require the simultaneous existence of two or more mutually exclusive trajectories). The appearance of a paradox depends on the assumption that universality and particularity are static.

The introduction of the idea of motion not only resolves the apparent paradox (as Hansberry did in 1959 with her assertion that universality flows out of particularity). but also illuminates the reasons for the illusion of - and the cultural need for - the paradox: to view the "universal" and the "particular" as a dialectic rather than a pair of static opposites frozen in a paradox is to destabilize the "universal," that is, whiteness.

All the white critics' categorizations of the play - as particular, as distinctly not particular but universal, as apolitical, as a tokenized masterpiece - constructed black experiences as collectable. The unidirectionality of collecting (the fish cannot collect the humans outside the bowl) stabilizes whiteness and thus reifies white power. Hansberry's solution to the apparent paradox - that particularity and universality are not static. contradictory opposites - suggested that the fishbowl's glass does not exist (or at least that the glass is an unstable illusion), that blacks are not inherently collectable, that whites are not necessarily immune from being collected. Hansberry's resolution of the paradox, then, was anti-racist both in its content ("I'd always been under the impression that Negroes are people" ${ }^{\text {"33 }}$ ) and in its destabilization of the static categories of "universal" and "particular," "collector" and "collected" - categories on whose stability white power depends. White critics, then, maintained the illusion of the paradox - despite the availability of a simple solution - in order to stabilize both whiteness and the segregation of Negroes and whites, and thus to produce and enhance white power.

The level of desperation to maintain the paradox and thus stabilize whiteness is best appreciated through an examination of a misquotation in the New York Times that reversed Hansberry's fluid belief in universalism-throughparticularity. The progression of the misquotation, as described by Robert Nemiroff. Hansberry's ex-husband and literary executor, is worth quoting at length: 
[Hansberry] is ... "quoted" as follows: "I told them this wasn't a 'Negro play.' It was a play about honest-10-God, believable, many-sided people who happened to be Negroes."

In her scrapbook, beside a clipping of this interview, Lorraine wrote these words: "Never said NO such thing. Miss Robertson [the interviewer] goofed - letter sent posthaste - Tune in next week. ..." But she need not have waited. The letter of correction was never printed. A month later, in a second profile ("Her Dream Came True" 4/9/59), presumably by another writer, the alleged statement was repeated. And from there it spread like a prairie fire. In short order, a second "quote" was mysteriously appended to the first to complete the equation: "I'm not a Negro writer - but a writer who happens to be a Negro." And now nothing could stop it, for it seemed to solve the problem for white Americans - how to classify the author of "The Best Play of the Year" while, at the same time, avoid honoring the special qualities that made her what she was. By the time Lorraine died, the phrase had undergone, in the New York Times obituary, a further metamorphosis: "The work was described not as a Negro play but one about people who happen to be Negroes. And its author, t0o, insisted throughout her short lifetime that she was not a Negro playwright, but .... "etc.

Thus, the words Lorraine never spoke became in effect her credo as an artist, as if it were the driving passion of her life. ${ }^{34}$

The persistence and expansion of the misquotation (which can still be found in many scholarly texts) demonstrates the urgency and effort with which the paradox was maintained. The misquotation located Hansberry squarely within the universalist stance - but reacting to the particularist interpretation (in other words, it invoked the particularist interpretation as much as it did the universalist). The misquotation thus maintained the illusion of two mutually exclusive interpretations locked in battle with each other. It appeared to resolve the paradox (by using Hansberry's authority as the writer and as a "Negro" to "prove" the universalist interpretation and "discredit" the particularist position), but in fact it merely maintained it by erasing the possibility of a fluid relationship between the universal and the particular.

Fluidity was also frozen (and thus the paradox was maintained and whiteness stabilized) through critics' re-invention of Raisin as a "timeless classic." Upon the play's opening, the question of whether the play was timely or timeless arose as immediately as the question of whether it was universal or specific to black culture. "We do not know if Miss Hansberry has written a timeless play," wrote a reviewer for the Philadelphia Inquirer, "but she certainly has written a timely one." 35 George Murray noted in the Chicago American that the play "couldn't be better timed for box office success. Its advent coincides with a rising wave of general interest in the Negro. The wave began as a groundswell after World War II. It is visible in the South's integration fight, in high court decisions, the National Association for the Advancement 
of Colored People's muscle-flexing." ${ }^{30}$ With the benefit of twenty years" hindsight. Bennetl observed, "the timing [of the play's opening] was perfect. Remember, this was 1959, five years after the Supreme Coun decision on school desegregation, four years after Montgomery, the eve of the sit-ins. The time was ripe for Lorraine Hansberry. She was a kind of herald, a person announcing the coming of something. It was in the air, I think, and whites felt it as well as Blacks."

Before long, the votes swung overwhelmingly in the direction of dubbing $A$ Raisin in the Sun "timeless," that is, a masterpiece. Upon the play's revival in 1983. Lloyd Richards, director of the original production, called the play "a timeless piece." ${ }^{38}$ As Wilkerson observed, A Raisin in the Sun is one of the only black plays ever to have been "accorded the status of a classic." ${ }^{39}$

The process by which classics or masterpieces are so labeled is politically charged, to say the least. When the artistic work slides along the dialectic of universality and particularity (i.e., when the work is labeled "ethnic"), however, the political ramifications become even more acute. As Clifford observed, some collectable "ethnographic specimens" (as the particularists viewed Raisin) are recognized as artistic masterpieces because they fit socalled "universal" aesthetics. ${ }^{40}$ To label an "ethnically specific" play a "masterpiece," then, is to label it exceptional, to separate it from its ethnic tradition. It was impossible in 1959 - and it is arguably still impossible today - to label the work of a minority artist a "masterpiece" without simultaneously asserting its universality. In other words, the process of labeling a "minority" play a masterpiece necessarily invoked and engaged with the apparent paradox of universality versus particularity. The creation and maintenance of the illusion of the paradox enables some "exceptional" works by minorities to be declared masterpieces and simultaneously facilitates the relegation to the back of the bus of artistic works labeled "non-masterpieces." The "paradox," in other words, acts as a gate to separate (or stabilize the separation of) "masterpieces" from "non-masterpieces," white from black, collector from collected, "universal" from "particular," "timeless" from "timely." And as the "paradox" acts as a gate, those with the power to maintain the illusion of the paradox (e.g.. white critics) invent themselves as gatekeepers.

Lerone Bennett. Jr., was correct when he called Hansberry "a kind of herald, a person announcing the coming of something," as when he described a nameless something "in the air ... and whites felt it as well as Blacks." ${ }^{1}$ Perhaps that subconsciously anticipated "something" - so feared by the creators and maintainers of the paradox - was a postmodern, globalized culture in which boundaries between universal and particular, white and nonwhite, collector and collected, are unstable. A world in which the subaltem speaks back: in which culture flows not only from the "top-down," but in all chaotic directions; a world, in the words of Arjun Appadurai, in which "the United States [and by extension, whiteness] is no longer the puppeteer of a world system of 
images, but is only one node of a complex transnational construction of imaginary landscapes." 42 Through the desperate creation and maintenance of the appearance of the paradox - which in tum created and maintained a static boundary between universal and particular, white and black - white people created the illusion that they could collect minority experiences without being collected themselves.

\section{NOTES}

1 George Murray, "'Raisin in Sun' Terrific Theater," Chicago American (27 February 1959), 19.

2 Sydney J. Harris, "Sydney Harris Reviews: 'A Raisin in the Sun,"' Chicago Daily News (11 February 1959). 39.

3 George Oppenheimer, "On Stage," newspaper unknown (25 March 1959), in file, "A Raisin in the Sun: Clippings," Billy Rose Collection, New York Public Library for the Performing Arts.

4 Claudia Cassidy, "On the Aisle: Warm Heart, Backbone, Funnybone in Blackstone Play and Cast," Chicago Daily Tribune (12 February 1959), F1.

5 Brooks Atkinson, "A Raisin in the Sun," in On Stage: Selected Theater Reviews from The New York Times, 1920-1970, ed. Bernard Beckerman and Howard Siegman (New York, 1970), 402.

6 "A Simple Story: Triumph of Negro Pride," London Times (5 August 1959), n.p., in file, "A Raisin in the Sun: Clippings," Billy Rose Collection, New York Public Library for the Performing Arts.

7 Lorraine Hansberry [assembled and edited by Robern Nemiroff], To Be Young. Gifted, and Black (New York, 1970), 128.

8 Lerone Bennett, Jr., and Margaret G. Burroughs, "A Lorraine Hansberry Rap," Freedomways: A Quarterly Review of the Freedom Movement, 19 (1979): 232.

9 I have chosen not to attempt to create any chronology of criticism. In other words, I have not traced the ways in which the play's critical reception changed over time, nor have I foregrounded time as an important factor in this study. My purpose in this paper is not to write a history of the play's critical reception, but rather to unpack the ideas that have swirled around the play from 1959 until today. Also because I am not foregrounding any chronology, I use the words "AfricanAmerican" and "black" interchangeably when I refer to people of a non-specified time; I use "Negro" only when I refer specifically to blacks prior to the early I960s.

Io Lorraine Hansberry, "Willie Loman, Walter Younger, and He Who Must Live," The Village Voice (12 August 1959), 7. 8 (original emphasis). In this article, the word "racial" was misprinted as "radical"; however, on 19 August , the Voice corrected it to "racial." I have corrected the quote for ease in reading.

11 Ibid., 8.

12 Ibid. 
13 Elliot Norton. ''A Raisin in the Sun' Bristles with Power." Boston Record (1 3 September 1960), $\mathrm{C}_{74}$.

14 Frank Ashton and Brooks Atkinson, respectively, quoted in Lorraine Hansberry. A Raisin in the Sun (New York, 1966), back cover.

I5 James Clifford, The Predicament of Culture: Twentieth-Century Ethnography. Literature, and Art (Cambridge. MA. 1988), 215.

16 Ibid.. 218.

17 Ibid., 231 .

18 lbid.. 200.

19 Donna Haraway, Primare Visions: Gender, Race, and Nature in the World of Modern Science (New York, 1989), 34.

20 Hansberry, "Willie Loman," 8 (original emphasis). See note 10.

21 Ibid., 8.

22 The assertion that the characters are not stereotyped is not without controversy. Many critics, both black and white, have noted that the play "abounds with types: Mama is a tyrannical but good-natured matriarch; Walter, a frustrated young man surrounded by too many women; Beneatha, a free-thinking college student; the African Asagai, a poetic revolutionary; and the one white man, a cliche-ridden suburbanite" (Doris E. Abramson, Negro Playwrights in the American Theatre, 19251959 [New York. I967], 254). In particular, the character of Mama was "charged by critics" with being "a reactionary black "mammy" (Adrienne Rich, "The Problem with Lorraine Hansberry," Freedomways: A Qwarterly Review of the Freedom Movement, I9 [1979], 252) - a characterization vociferously contradicted by black writers such as Amiri Baraka and Margaret B. Wilkerson (Amiri Baraka, "'Raisin in the Sun's' Enduring Passion," The Washington Post [16 November I986], n.p, in file. "'A Raisin in the Sun: Clippings," Billy Rose Collection, New York Public Library for the Performing Arts; Margaret B. Wilkerson, “A Raisin in the Sun: Anniversary of an American Classic," in Performing Feminisms: Feminist Critical Theory and Theatre, ed. Sue-Ellen Case [Baltimore, 1990], 122, 125, 128). The point is not that the play was necessarily devoid of stereotypes, but rather that any stereotypes it may have contained were certainly far less pronounced and racist than those of minstrelsy.

23 Wilkerson. "Anniversary," 122. See note 22.

24 Lorraine Hansberry, quoted in Nan Robertson, "Dramatist Against Odds," New York Times (8 March I959), in file, "A Raisin in the Sun," Schomburg Collection, New York Public Library; quoted in Abramson, 240.

25 Elizabeth Brown-Guillory, Their Place on the Stage: Black Women Playwrights in America (Westport, CT, 1988), 34-

26 Alex Haley, "The Once and Future Vision of Lorraine Hansberry," Freedomways: A Quarterly Review of the Freedom Movement, 19 ( 1979), 279.

27 lbid, 278-79.

28 Margaret B. Wilkerson, "Lorraine Hansberry: The Complete Feminist," Freedomways: A Quarterly Review of the Freedom Movement, 19 (1979), 237. 
29 Bennett and Burroughs, 230 . See note 8.

30 Margaret B. Wilkerson, "Critics, Standards and Black Theatre," in The Theater of Black Americans: A Collection of Critical Essays, ed. Errol Hill (New York, 1987), 319.

31 In an interesting variation, some critics argued that Hansberry's characters were universal minorities. For example, the characters "could belong to almost any minority race or sect"; Raisin "could be a play by Clifford Odets about Jews in the Bronx" or "could just as easily be about Jews or Communists" (Oppenheimer, 19; Milton Shulman, "I Fear We've Heard this Note Before," Evening Standard [5 August 1959], n.p., in file, "A Raisin in the Sun: Clippings," Billy Rose Collection, New York Public Library for the Performing Arts; Don Cook, "'Raisin in the Sun' vs. London Critics, New York Herald Tribune [30 August 1959], n.p., in file, "A Raisin in the Sun: Clippings," Billy Rose Collection, New York Public Library for the Performing Arts). The reviewers thus used Raisin simultaneously to erase differences among minority cultures. to segregate and marginalize all such cultures from the white majority, and thus to center and empower white gentiles.

32 Clifford, 193. See note 15.

33 Hansberry, To Be Young, 128. See note 7.

34 Robert Nemiroff, "A Lorraine Hansberry Bibliography," Freedomways: A Quarterly Review of the Freedom Movement, 19 (1979), 286-87.

35 Henry T. Murdock, "Poitier in Timely Play on Trials of Negroes," Philadelphia Inquirer (27 January 1959), n.p., in file, "A Raisin in the Sun: Clippings," Billy Rose Collection, New York Public Library for the Performing Arts.

36 Murray, 19. See note 1.

37 Bennett and Burroughs, 229.

38 Samuel G. Freedman, "Yale Marking 25th Anniversary of Raisin in Sun," New York Times ( I November 1983), C1 3, quoted in Wilkerson, "Anniversary," 119.

39 Wilkerson, "Anniversary." I 19.

40 Clifford, 206.

41 Bennett and Burroughs, 229.

42 Arjun Appadurai, "Disjuncture and Difference in the Global Cultural Economy," in The Phantom Public Sphere, ed. Bruce Robbins (Minneapolis, 1993), 273. 
Copyright $@ 2003$ EBSCO Publishing 